\title{
The functional properties of starches, physico-chemical and sensory properties of salad cream from cassava and potatoes
}

\author{
Eke-Ejiofor J., Owuno F. \\ Department of food science and Technology, Rivers State university of Science and Technology, Port-Harcourt, Nigeria
}

\section{Email address:}

joyekee@yahoo.co.uk (Eke-Ejiofor J.)

\section{To cite this article:}

Eke-Ejiofor J., Owuno F.. The Functional Properties of Starches, Physico-Chemical and Sensory Properties of Salad Cream from Cassava and Potatoes. International Journal of Nutrition and Food Sciences. Vol. 3, No. 6, 2014, pp. 567-571. doi: 10.11648/j.ijnfs.20140306.22

\begin{abstract}
The Physicochemical, sensory properties and viscosity of salad cream stabilizes with cassava and potato starches were investigated, with commercial salad cream used as control. Cassava and potato starches were processed using standard methods. The functional properties of cassava and potato starches showed that dispersibility were $84-86 \%$, swelling power were $6.20-8.19 \%$ and solubility were $13-14 \%$ with no significant difference $(\mathrm{p}>0.05)$ between the starches. Although water and oil absorption capacities were $19.7-27.7 \%$ and $9.20-11.30 \%$ respectively. Water and oil absorption capacities showed a significant difference $(\mathrm{p}<0.05)$ between the starches. Chemical analysis results showed that moisture content were 57.84$64.88 \%$, dry matter were 42.16-54.69\%, starch content were $6.40-14.41 \%$ and total available carbohydrate (TAC) ranged from $7.11-17.32 \%$ respectively with potato starch based salad cream having the least and the control(commercial salad cream) having the highest. $\mathrm{pH}$, total solids, protein and fats were $3.14-3.50,35.12-42.16 \%, 0.23-0.35 \%$ and $25.17-28.15 \%$ respectively with the control having the lowest value and potato based salad cream having the highest. Total Titratable Acidity (TTA) had potato based salad cream as the lowest (0.02) and cassava based salad cream as the highest (0.89), while ash had (1.62\%) as the lowest for cassava starch based salad cream and (1.83\%) as the highest for the control. Moisture, dry matter, total solid, starch, fat and total available carbohydrate showed a significant difference $(\mathrm{p}<0.05)$ amongst the samples while total acidity, $\mathrm{pH}$, protein and ash showed no significant difference $(\mathrm{p}>0.05)$. Sensory analysis result showed that color were 3.36-4.24, taste were 2.54-3.88 and spreadability were 3.52-4.36 with the three parameters showing a significant difference $(p<0.05)$ amongst the samples, while odour, texture and general acceptability showed no significant difference ( $\mathrm{p}>0.05)$ and were 3.44-3.76, 3.56-3.96 and 3.80-3.88 respectively. The viscosity result of the salad cream samples showed that potato based salad cream had the highest viscosity at varying speeds of 6,12, 30 and 60rpm followed by the control and cassava based salad cream. All salad cream samples exhibited a non Newtonian behaviour.
\end{abstract}

Keywords: Functional, Cassava, Potato, Starches, Physicochemical, Sensory, Salad Cream

\section{Introduction}

Salad cream is a creamy, yellow condiment based on an emulsion of about $25-50$ percent of oil in water, emulsified by egg yolk and acidified by spirit, vinegar, and other ingredients which may include sugar, mustard, salt, thickener, spices, flavouring and colouring. According to Food and Drug Administration (FDA), salad dressing is defined as a semi- solid emulsified food with the same ingredient and optional ingredient as mayonnaise with the exception of cooked starch (1) (Colye, 1982)

It is a readymade creamy-white dressing with a flowing consistency for eating with salad, (mixture of raw vegetable). It is prepared with various ingredients of which modified maize flour serves as the base raw material (2) (Turgeon, 1996).

For people unfamiliar with salad cream, the condiment is probably similar to mayonnaise in term of composition and texture, although salad cream is slightly yellowish, rather than white and the flavour of salad cream is a bit complex.

Depending on the brand and style, salad cream may be lower in fat content than traditional mayonnaise or roughly equivalent and it can be spicy to sweet (2)(Turgeon, 1996).

The presence of starch in salad dressing serves as a gelling, binding, thickening, emulsifying agent and a stabilizer 
(3)(McCance and Widdowson 1987).

Fresh roots and tubers such as (cassava and potato) are highly perishable and a lot of post-harvest losses occur as a result of the inherent high moisture content of fresh roots which promote both microbial deterioration and undesirable biochemical changes in the commodity (4) (Wenham 1995). This limits their availability and usage as a raw material to the industries that needs them, but is largely processed and used as traditional household food and as animal feed. However, one of the major processing indices of root and tuber is their ability to gelatinize and form thick paste for human consumption. The gelatinization process is a property of the starch granule found in cereals and tuber crop (5) (Iwe et al., 1999). In Nigeria, cassava and potato are consumed and utilized in many different forms such as gari, fufu, chips, tapioca and others. There is therefore need to diversify the usage of cassava and potato other than its preparation into traditional household food product.

Therefore the objectives of this work are

To determine the functional properties of cassava and potato starches.

To determine the chemical and sensory properties of cassava and potato based salad cream.

\section{Materials and Methods}

\subsection{Materials}

Cassava root were obtained from the Rivers State University of Science and Technology school farm, while sweet potato tubers were obtained from National Root Crop Research Institute (NRCRI) Umudike and processed within 24 hours after harvest.

Chemicals used for the analysis were obtained from the Biochemistry laboratory, Department of Food Science and technology, Rivers State University of Science and Technology.

\subsection{Methods}

\subsubsection{Processing of Starch}

The method described by (6) Osunsami et al., (1989) with slight modification was used for the production of various starches.

\subsubsection{Preparation of Cassava and Potato Based Salad Cream as Described by Ashaye et al; 2010}

Dry cassava and potato starches were reconstituted with water respectively. Vinegar, salt, sugar and mustard were added and then cooked over heat while stirring continuously until gelatinization occurred (translucent). This was then cooled at refrigeration temperature and blended in a warring blender for one minute at low speed after which egg yolk and vegetable oil were added and further blended for another five minutes. The resultant salad cream was then poured into covered container respectively and stored for further analysis.

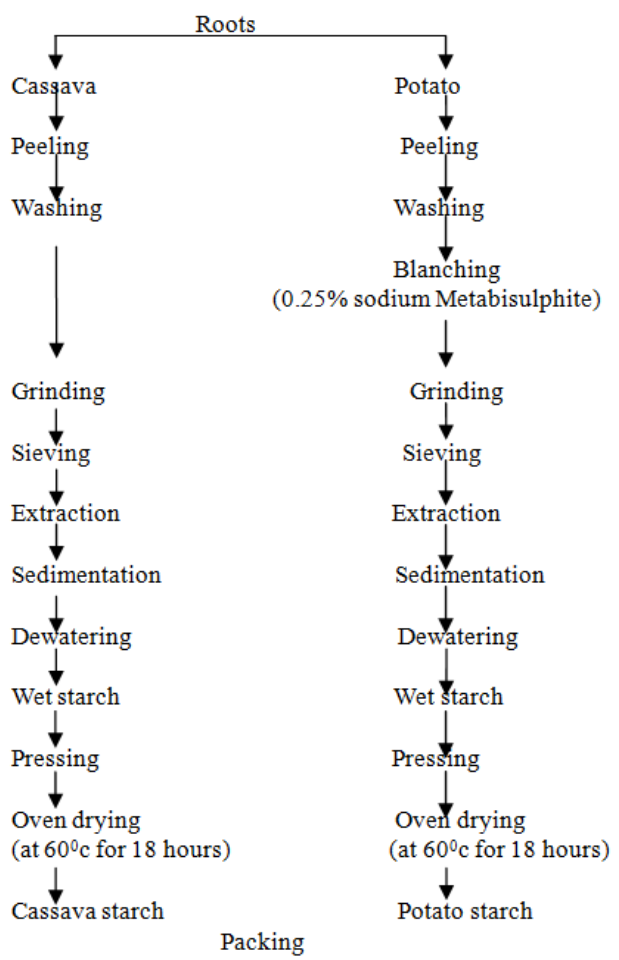

Fig 1. Flow Chart for the production of cassava and potato starches.

Source: Osunsami et al., 1989 (Modified)

\subsubsection{Chemical Analysis of Salad Cream}

Moisture, ash, crude protein and fats were determined by the (7) AOAC (1990) method. Crude fiber was estimated by the method of (8) Mayanard (1970. The carbohydrate content was calculated by difference, (100- sum of the values for moisture, crude protein, crude fiber, crude fat and crude ash). (9) (Raghuramulu et al., 1983). Starch and Sugar were determined by the method described by (10) Dubois et al., (1956) as described in (11) Eke-Ejiofor and Kiin Kabari, 2010. Amylose content was determined by the method described by (12) Williams et al (1970)

\subsubsection{Viscosity Determination}

The viscosity of the different salad cream samples (cassava, potato and control) were measured in triplicate with the aid of a rotary digital viscometer (NDJ-8S). There readings were taken per sample at $0.6 \mathrm{rpm}, 1.5 \mathrm{rpm}$ and 3.0rpm. Spindle No 4 was used for all measurements with $300 \mathrm{mls}$ of samples in a $500 \mathrm{ml}$ beaker.

\subsubsection{Sensory Evaluation}

The salad cream made from cassava and potato starches were subjected to sensory analysis and Heinz salad cream used as control. A total of twenty five panelists who were familiar with salad cream and neither sick nor allergic to starch based products were used. The samples were rated for color/appearance, odor, taste, texture, spreadability and general acceptability. A questionnaire was drafted and administered to assess these attributes using a 5 point hedonic scale. 


\subsubsection{Functional Properties of Starches Used for Salad Cream}

Dispersibility was determined by the method described by (13) Kulkani et al., (1991). Swelling power and solubility were determined by the method described by (14) Takashi and Sieb (1988). Water/Oil absorption capacity (WAC)/ (OAC) were determined by the method described by (15) Sosulski (1962). Bulk density was determined by the method of (16) Naragana and Narasinga Rao (1984).While least gelation concentration and color indices were determined by the method of (17) Coffman and Garcia (1977) and (18) Francis (1998) respectively.

\subsection{Statistical Analysis}

Statistical analysis of data was done using analysis of variance (ANOVA) and means were separated by the least significant difference (LSD) procedure (19) (Larmond, 1977).

\section{Results}

\subsection{Functional Properties of Potato and Cassava Starches}

Table 1 shows the functional properties of the starches before value addition. Dispersibility, swelling power, solubility, water absorption capacity and oil absorption capacity of the starches were evaluated. Functional properties are the characteristics that determine the suitability of the food material for specific purpose. Dispersibility of the starches weres $84.00 \%-86.00 \%$ with cassava starch having the least dispersibility and potato starch having the highest. The higher the dispersibility, the better the reconstitutional properties of the starches which has a marked effect on gel quality.

Swelling power were $6.20 \%-8.19 \%$ with cassava starch recording the highest value swelling and potato starch recording the least while solubility ranged from $13.00 \%$ $14.00 \%$ with cassava starch having the highest and potato starch having the least. The swelling power and solubility values of sweet potato starch in this study is lower than the previous works reported by (11) Eke-Ejiofor and Kiin-Kabari (2010) but agrees with the fact that swelling and solubility of sweet potato starch are less than that of cassava but generally more than those of maize. Water absorption capacity and oil adsorption capacity were $197 \%-277 \%$ and $9.20 \%-11.30 \%$ respectively. Cassava recorded the highest and potato starch the least. Water absorption capacity value of potato starch which was lower than that of cassava starch may be as a result of cassava having a weaker internal structure (20) (Pomeranze, 1991). Water absorption capacity is a function of water holding ability of the starch sample. It is an important processing parameter that has implication for viscosity.

Table 1. Functional properties of cassava/potato starches

\begin{tabular}{llllll}
\hline Sample & Dispersibility & Swelling power & Solubility & Water absorption capacity & Oil absorption Capacity \\
\hline PSC & $86.00^{\mathrm{a}}$ & $6.20^{\mathrm{a}}$ & $13.00^{\mathrm{a}}$ & $277^{\mathrm{a}}$ & $11.30^{\mathrm{a}}$ \\
CSC & $84.00^{\mathrm{a}}$ & $8.19^{\mathrm{a}}$ & $14.00^{\mathrm{a}}$ & $197^{\mathrm{b}}$ & $9.20^{\mathrm{a}}$ \\
LSD & 0.62 & 1.57 & 0.85 & 1.42 & 0.98 \\
\hline
\end{tabular}

* Values with the same superscripts in the same column are not significantly different $(\mathrm{p}>0.05)$

Key:

PS - Potato starch

CS - Cassava starch

LSD - Least significant difference

\subsection{Chemical Analysis of Salad Cream}

Table 2 shows the chemical properties of salad creams stabilized with potato and cassava starches. Moisture content of the various salad cream were $57.84 \%$ - $64.88 \%$ with control (commercial salad cream) having the highest moisture content of $64.88 \%$ and the potato starch based salad cream having the lowest moisture content. Low moisture content is an indication of better storability and shelf life. The moisture content in this study is higher than that reported by (21) Ashaye et al (2010) of 48.99\% and (22) Babajide and Olatunde (2010) who reported a range of $48.80-49.79 \%$ for corn-cocoyam based salad cream. There was a significant difference $(\rho>0.005)$ in all the samples.

Dry matter, starch and total available carbohydrate content ranged from $42.16 \%-54.69 \%, 6.40 \%-14.41 \%$ and $7.11 \%$ $17.32 \%$ with the control having the highest and potato starch based salad cream having the lowest respectively. Dry matter in this study was lower than that of (21) Ashaye et al (2010), while starch was higher.

Total available carbohydrate (TAC) ranged from 7.11\% -
$17.32 \%$ with the commercial salad cream having the highest in TAC (17.32\%). The Heinz salad cream in this study agrees with that reported by (22)Babajide and Olatunde (2010). (3)McCance and widdowson (1987) also reported a carbohydrate content of $17.68 \%$ and $18.96 \%$ for Heinz and cassava based salad cream. The difference recorded could be as a result of method of preparation and the starch origin. Total Titratable Acidity (TTA) were $0.02-0.89$ with potato starch (PS) recording the least and cassava starch (CS) recording the highest.

$\mathrm{pH}$ of the samples were $3.14-3.50$ with control having the least and potato starch salad cream (PSSC) having the highest value. The $\mathrm{pH}$ value of $3.14-3.40$ is in agreement with the result reported by (21) (Ashaye et al., 2010). pH is also an indication of the keeping quality of the product. Total solid content were $35.12 \%-42.16 \%$ with potato salad cream having the highest $(42.16 \%)$ and the control having the least (35.12\%).

Protein content were $0.23 \%-0.35 \%$ with cassava starch salad cream (CSSC) and Heinz salad cream (HSC) samples 
having the least, while potato starch salad cream (PSSC) having the highest. This finding showed no significant difference of $(p>0.05)$ in all the samples. The result falls within the range recorded by (21) Ashaye et al., (2010) of $0.37 \%-1.61 \%$. Starch content were $6.40 \%-14.41 \%$ with potato starch salad cream (PSSC) recording the least and control recording the highest.

Fat content were $25.17 \%-28.15 \%$ with control recording the least while potato starch salad cream (PSSC) recorded the highest. This result falls within the range recorded by (21)Ashaye et al., 2010 who reported a range of $6.66 \%$ $28.71 \%$ and also (22)Babajide and Olatunde (2010) who reported fat content of $27.04 \%-29.68 \%$ for corn- cocoyam based salad cream. In addition (3)McCance and Widdowson (1987) reported an average fat content of $31 \%$. The study showed a significant difference $(\rho<0.05)$ in the various salad cream with respect to their fat content.

Ash content were $1.62 \%-1.83 \%$ with cassava salad cream recording the least and control recording the highest. Higher values reported in this product is not unrelated to the difference in method of preparation. Different method of preparation affect the compositional attributes of any food product (21) (Ashaye et al., 2001,(23) Saxema et al., and (24)Vilai et al., 2001).

Table 2. Physico-chemical properties of cassava/potato based salad cream

\begin{tabular}{|c|c|c|c|c|c|c|c|c|c|c|}
\hline Sample & $\begin{array}{l}\text { Moisture } \\
\text { content \% } \\
\end{array}$ & $\begin{array}{l}\text { Dry } \\
\text { matter \% }\end{array}$ & $\begin{array}{l}\text { Titratable } \\
\text { acidity }\end{array}$ & pH & $\begin{array}{l}\text { Total } \\
\text { solid \% }\end{array}$ & Protein \% & Starch \% & Fat $\%$ & Ash \% & TAC $\%$ \\
\hline PSSC & $57.84^{\mathrm{c}}$ & $42.16^{\mathrm{b}}$ & $0.02^{\mathrm{a}}$ & $3.50^{\mathrm{a}}$ & $42.16^{\mathrm{a}}$ & $0.35^{\mathrm{a}}$ & $6.40^{\mathrm{b}}$ & $28.15^{\mathrm{a}}$ & $1.7^{\mathrm{a}}$ & $7.11^{\mathrm{c}}$ \\
\hline CSSC & $62.61^{\mathrm{b}}$ & $42.89^{\mathrm{a}}$ & $0.89^{\mathrm{a}}$ & $3.21^{\mathrm{a}}$ & $37.39^{\mathrm{b}}$ & $0.23^{\mathrm{a}}$ & $6.94^{b}$ & $26.04^{\mathrm{b}}$ & $1.62^{\mathrm{a}}$ & $7.70^{\mathrm{b}}$ \\
\hline HSC & $64.88^{\mathrm{a}}$ & $54.69^{\mathrm{a}}$ & $0.12^{\mathrm{a}}$ & $3.14^{\mathrm{a}}$ & $35.12^{\mathrm{b}}$ & $0.23^{\mathrm{a}}$ & $14.41^{\mathrm{a}}$ & $25.17^{\mathrm{b}}$ & $1.83^{\mathrm{a}}$ & $17.32^{\mathrm{a}}$ \\
\hline LSD & 1.40 & 2.64 & 2.83 & 1.18 & 1.40 & 1.18 & 1.05 & 1.18 & 1.72 & 1.18 \\
\hline
\end{tabular}

Values with the same superscripts in the same column are not significantly different $(\mathrm{p}>0.05)$

Key:

PSSC - Potato starch based salad cream

CSSC - Cassava starch based salad cream

HSC - Heinz salad cream (control)

LSD - Least significant difference

\subsection{Sensory Evaluation}

Table 3 shows the sensory analysis result of potato and cassava starch based salad cream and commercial salad cream used as control. Color/Appearance by physical examination ranged from $3.36 \%-4.24 \%$ with the control having the lowest and potato starch salad cream (PSSC) having the highest $(4.24 \%)$. The result showed greater likeness for the color of potato based cream over the cassava based and the Heinz salad cream.

Taste were $2.54 \%-3.88 \%$ with potato starch salad cream (PSSC) having the lowest (2.54\%), while spreadability were $3.52 \%-4.36 \%$ with control having the highest and potato starch salad cream (PSSC) having the lowest. Spreadability result obtained for potato in the present study may be as a result of low water absorption capacity of its starch. Color, taste and spreadability showed a significant difference ( $\rho>0.05$ ) amongst the samples. Odor were $3.44 \%-3.76 \%$ with Heinz salad cream (HSC) scoring the highest and cassava salad cream (CSSC) scoring the lowest.

Texture were $3.56 \%$ - 3.96\% with (CSSC) having the highest and PSC having the lowest. General acceptance were $3.80 \%-3.88 \%$ with CSSC having the highest and PSC having the least even though odor, texture and general acceptability showed no significant difference $(\rho<0.05)$ amongst the samples.

Cassava and potato starch based salad cream competed favorably with the control in terms of sensory characteristics.

Table 3. Mean sensory scores of cassava and potato based salad cream

\begin{tabular}{|c|c|c|c|c|c|c|}
\hline Sample & Color/Appearance & Odor & Taste & Texture & Spreadability & General Acceptance \\
\hline PSSC & $4.24^{\mathrm{a}}$ & $3.64^{\mathrm{a}}$ & $2.54^{\mathrm{c}}$ & $3.96^{\mathrm{a}}$ & $3.52^{\mathrm{b}}$ & $3.84^{\mathrm{a}}$ \\
\hline CSSC & $3.88^{\mathrm{b}}$ & $3.44^{\mathrm{a}}$ & $3.20^{\mathrm{b}}$ & $3.56^{\mathrm{a}}$ & $3.84^{\mathrm{a}}$ & $3.88^{\mathrm{a}}$ \\
\hline HSC & $3.36^{\mathrm{c}}$ & $3.76^{\mathrm{a}}$ & $3.88^{\mathrm{a}}$ & $3.60^{\mathrm{a}}$ & $4.36^{\mathrm{a}}$ & $3.80^{\mathrm{a}}$ \\
\hline LSD & 0.20 & 0.58 & 0.24 & 0.59 & 0.67 & 0.62 \\
\hline
\end{tabular}

Values with the same superscripts in the same column are not significantly different $(\mathrm{p}>0.05)$

Key:

PSSC - Potato starch based salad cream

CSSC - Cassava starch based salad cream

HSC - Heinz salad cream (control)

LSD - Least significant difference

\subsection{Viscosity}

Fig 2 shows the viscosity of salad cream prepared from cassava, potato starches and control at different shear rate and temperature. There was a great interaction in their behavior. All samples exhibited a pseudo plastic behavior (Non Newtonian behavior) as their shear rate increased the viscosity decreased at lowest shear, exhibiting a thinning properties (25)(Morris,1989). The highest viscosity was observed with potato starch based salad cream. 


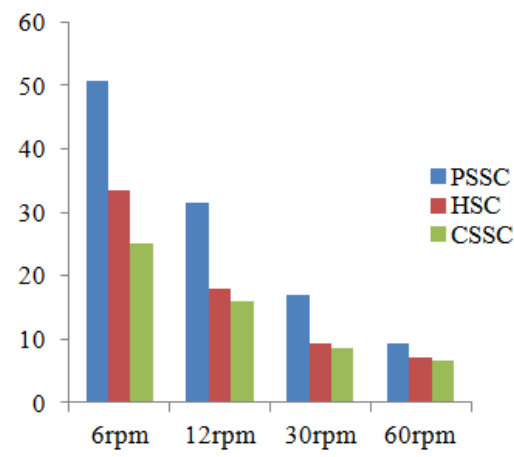

Fig. 2. Viscosity of cassava/potato starches based salad cream

Key:

PSSC - Potato starch based salad cream

HSC - Heinz salad cream (control)

CSSC - Cassava starch based salad cream

\section{Conclusion}

From the results obtained in this study, it can be concluded that Cassava/Potato based salad cream compared favorably with the control in the chemical, functional, sensory and viscosity of the salad cream. Cassava or potato starch can be substituted in place of corn starch in the production of salad.

\section{References}

[1] Colye, L.P. Jr(1985): The World Encyclopedia of food. New York Facts on file

[2] Turgeon, S. L., Senchez, C., Gauthier, S. I. and Puguin, P. (1996). Stability and rheological properties of salad dressing containing peptidic fractions of whey protein. International Diary Journal; 6, 645-658.

[3] McCance, R.A and Widdowson, E.M (1987): The composition of food. 5thedition. Royal society of chemist and Ministry of Agriculture, fisheries and food.

[4] Wenham, J. E. (1995). Post harvest deterioration of cassava. A Biotechnology perspective. FAO plant production and protection. Paper 130 Rome 6: 35.

[5] Iwe, M. O., Wolters, T., Govt, G., Stolp, W., Van Zurliccchem, D. Y., (1999). Behaviour of gelinization and viscosity of soysweet potato into mixture by single screw extrusion: A response surface analysis.

[6] Osunsani, a. T., Akingbala, Y.O., Oguntimehin, G. B. (1989). Effect of storage on starch content and modification of cassava, starch/starch starke 41: 54-57.

[7] AOAC (1990), Official Methods of analysis, Association of Official Analytical Chemists, $15^{\text {th }}$ edition, Washington D.C.

[8] Mayanard, A.J. (1970). Methods in Food Analysis, Academic Press, New York, P. 176.

[9] Raghuramulu, N., Nair, M.K. and Kalyansundaram, S. (1983): In: A Manual of Laboratory Techniques, NIN, ICMR, Hyderabad, India.
[10] Dubois, M., Gilles, K.A. Hamilton, J.k., Reberts, P.A and Smith, F. (1956) "Colorimetric method for determination of sugar and related substances", Anal chem. 28:350-356. As reported by Eke (2006) PhD Thesis.

[11] Eke-Ejiofor J. and Kin-Kabari D.B. (2010): Chemical Properties of Sweet and Irish Potato Chips. Nigerian Food Journal, 28(2): 47-52.

[12] Williams, P. C. Kuzina, F. D. and Hlynka IO. A. (1970). A Rapid Calorimetric Producer for Estimating the Amylase content of Starches and Starch. Cereal Chemistry 47(4): 411413.

[13] "Sorghum altbased Weaning Formulations Preparation, Functional properties and Nutritine values". Food and Nutrition Bulletin 13(4): 322-327.

[14] Takashi, S. and Sieb, P. A. (1988) "Paste and Gel properties of Prime corn and wheat starches with and without native lipids" Cereal chem 65: 474-475.

[15] Sosulski, F.N (1962): "The centrifugal method for determining flour absorptivity in hard red spring wheat" Cereal Chemistry 39:344-346.

[16] Narayana, K and Narasinga, Rao Ms (1984): Effect of partial proteolysis on the functional properties of winged pea (Psophocapus tetragonolobus) flour. Journal of Food Science, 49:944-947.

[17] Coffman A.W and Garcia V.V (1977); "Functional properties and amino acid content of protein isolate from mung bean flour." J. Food Science 48: 1654 - 1662.

[18] Francis, F. (1998): Color Analysis: In Food Analysis. S. S. Nlelsened Aspen Publishers Gaithersburg, USA pp. 559-612.

[19] Larmond, E (1977): Laboratory Methods for Sensory Evaluation of food. Canada pep Agric pub.

[20] Pomeranze, Y. (1991). Functional properties of food components. Academic Press, New York. 24: 7

[21] Ashaye, O. A., Lateef, S. O., Elizabeth, A. B., (2010). Physiochemical Rheological and Consumer acceptability of cassava starch cream. Journal of American Science 2010: 6(1) $65-72$.

[22] Babajide, J.M., and Olatunde. O.O.,(2010): Proximate composition, Rheological and sensory qualities of corncocoyam salad cream. World Journal of Dairy and Food science 5(1): 25-29.

[23] Saxema S, Gautam,S Sharma A. Physical, biochemical and antioxidant properties of some Indian honeys, Food Chem, doi 10.1016/j food chem. 2009.05.001 (In press, Accepted Manuscript).

[24] Vilai S, Kanjana K, Sunee C, Kuakoon P, Klananing S and Christopher G.O. Impact of water stress on yield and quality of cassava starch. Industrial crops and products 2001 13:115129.

[25] Morris, E. R., (1989). Polysaccharide solution properties origin rheological characterization and implication for food system in frontier in carbohydrate research - $1 \mathrm{n}$ food applications Millane, R. P., J. N. Bemiller and Chandrasekaran, Elsevier Applied Science New York. 145-148. 